\title{
Considerations about Teaching and Learning Process For Qualification Of Associate Degree Courses Professors In Using Virtual Learning Environments (Vles) At Fatec Jahu'
}

\author{
Antonio Eduardo Assis Amorim, Manuel de Jesus Lucas, Rosa Maria Padroni, \\ Véra Maria Ferro Merlini \\ Faculdade de Tecnologia de Jahu/CEETEPS
}

\begin{abstract}
Learning process is a mind process in that information is transformed into knowledge. Some professorshave interest to add new technologies to teaching practice; however, the Virtual learning is not used in its full power because it is not well-known and there is a large amount of professors who do not use it due to habit to his/her usual teaching methods besides presuming that its use may compromise his/her educational practices somehow and also because he/she will be frequently being tested about how the contents are shown.

This paper discusses about this perception and some clues to improve a better use of this technology.
\end{abstract}

\section{INTRODUCTION}

According to Lopes \& Gomes (2007), in the last decades the transformationsthat occurred on human beings and the Educational routesmust have been established by Society. In this context, the Information and Communication Technologies (ICTs) have a basic role in the transmission of information and knowledge, especially if it is taken into consideration the latest scientifical and technological improvements in that field. Several researchers, like Perrenoud (2000), Porto \&Régnier (2003), Novais (2004) andTusset (2006), among others, claim that the matter is not only have the Information and Communication Technologies(ICTs), but it is necessary to know how to use them. The use of ICTs has increased a lot in many countries, as it is presented in the "Livro Verde do ProgramaSociedade da Informação no Brasil" (Ministério da Ciência e Tecnologia, 2000), which shows that, in 1991, some regions had very little connection; however, in 1997, all countries were somehow connected.

Educationinvolves generating competences so human beings may take logical and reasonable decisions, well-founded and based in knowledge, avoiding the limited vision to empathize only the technological qualification instead of more relevant educational aspects which aimalways to develop the social inclusion and justice (Ministério da Ciência e Tecnologia, 2000). Assuming that the learning task involves a personal and group process, ANTUNES (2002) suggests that theICTs should be used to complete school and society in their basic mission: to offer the students the opportunity to improve their abilities to know how to learn, joining the ICTs to the person's development, in order that such process will result in learning and will allow the educator to know the different learning processes to understand how the brain creates and assimilates the knowledge. In Picture 1, the ICTs trends are shown (Lopes \& Gomes, 2007):

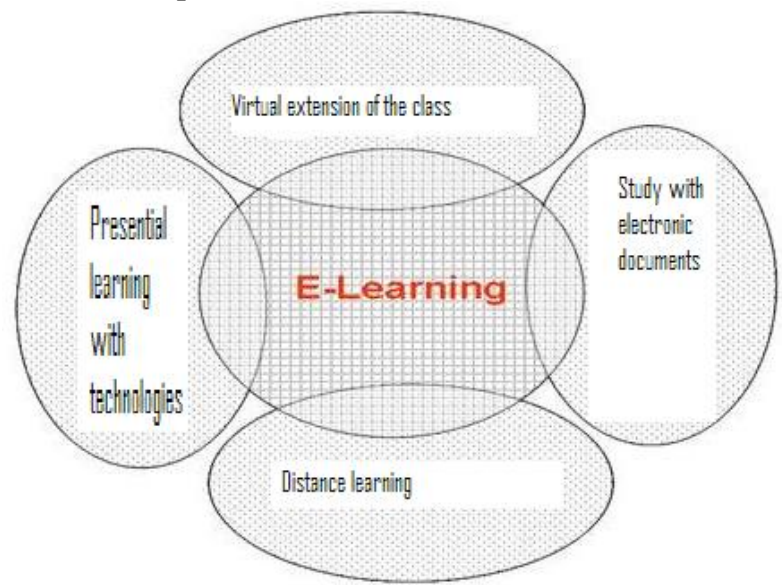

Picture 1.Trends in the use os ICTs for Teaching (Lopes \& Gomes, 2007)².

\footnotetext{
${ }^{1}$ Faculdade De Tecnologia De Jahu 
According to the Ministério da Ciência e Tecnologia (2000), the fast dissemination of information causes impacts at school and, to make such impacts even better, it is necessary and vital that the establishments have and offer the teachers an adequatebase. Theseimpacts are presented in Picture 2.

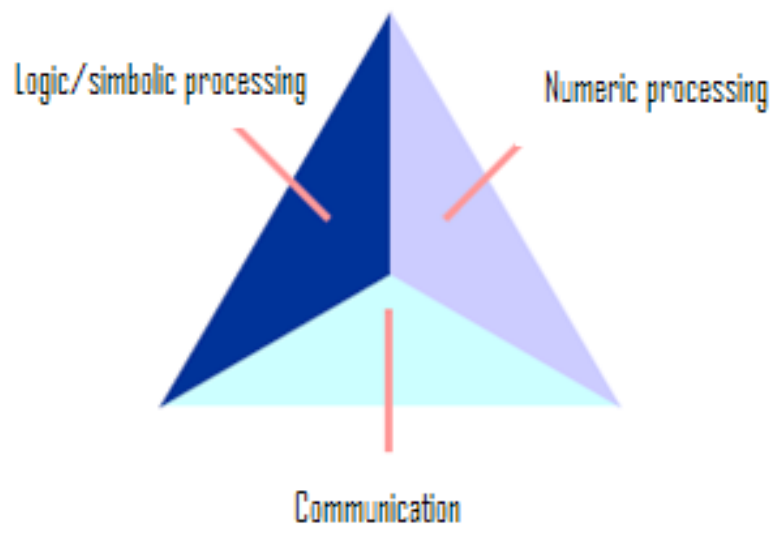

Picture 2.Impacts of ICTs at shcools.

Some teaching institutions have been used "at Distance Education"(aDE) as a simple extension to "at Present Education" (aPE) not taking into consideration the differences on conceptsbetween both learning environments, as well as the consequences that such action may cause. In Present Learning Environments (PLE), the learners are in the same space and oral communicationis usually the more used. In that environment it is easily possible to verify the actions and reactions of each partner, professor or student, besides it is easier to notice eventual direction changes on teaching/learning proposal. However, it is in such environment where the active agent, frequently, is the teacher. That scenery when it is not well accepted by the students or when there is not the necessary synergybetween the one who teaches and the one who learns, may cause significant quitting marks.

The PLEs are described when people are distant, in space and at time, and the written communicative channel is more commonly used. Because of that, in virtual teaching situations it is important to assure the interaction by means of strategies, as from the teacher when he/she prepares theoretical texts as in other situations that PLEs may provide (LITTO \& FORMIGA, 2009). Such didactic materials are the basis for the aDE currently, where the teacher has become the self-learning process guide more commonly than the content transmitter. The teacher is the educational mediator, organizing teaching strategies that must be in the Teaching Plan (MASETTO, 1998), setting the abilities to be developed and the competences to be reached. In spite of the professor's importance has been diminished when he/she adopts new teaching techniques, in fact just the opposite takes place as this environment is extremely flexible and leans to demand more and more efforts from the teacher, as the"self-learning" that characterizes the PLEs also are applied to whom proposes to teach and mediate learning necessarily.

It should be considered that aDEfacilitates an increasing interactionto the subject ant it may become a completing, integrant and substituting toolto aPE because it is an environment that allows the student to reflect and to include remarks and suggestions. Such new reality the learner is able to be an active partner in his/her new role which demands a flexible and engaged performance, just like the interaction in on line contexts proposes (MAIA \& MATTAR, 2007) (BARROS, 2003). The aDE processes are indispensable to the development of new efficient educational methodologies, of a new school culture and adequate tools for selfstudying or in groups. As the matter is about of quite new and inedited processes, it is commendable the use of quality indexes or "KPIs" (key performance indicators), as they are the ones which allow you to evaluate the efficiency of such processes, besides if the expected goals and objectives are being reached.

Synthetically, it may be stated that the school environment is the result of a team work process, involving teachers and students, and that aims to offer the learner, helped by the teacher and colleagues, to be more autonomous in task solution, transforming information into knowledge and acquiring new acknowledgements that will be part of his/her culture and knowledge by means of course contents.

At Fatec-Jahu, theVirtual Learning Environment (VLE) ${ }^{3}$ is placed by means of the MOODLE system (Modular Object-Oriented Dynamic Learning Environment), which is a free and open-source applicativeused to support

${ }^{2}$ https://repositorium.sdum.uminho.pt/bitstream/1822/7098/1/Challenges07-AML-MJG.pdf - accessed on Jan.16,2009

${ }^{3}$ www.learningcenter.com.br

DOI: 10.9790/0837-2109012630

www.iosrjournals.org

$27 \mid$ Page 
and manage collaborative learning activities, based on the social constructionist tradition. At present, such virtual environment has being used by few educators and even the few ones, have not used it properly in their educative practice, in view of such site main function has been as a file storage, and the other resources have not been put into use. This paper presents the diagnosis about the educators and students impressions and habits about ICTs in the cited teaching establishment.

\section{FATECJAHUACTION PROCESS -THE CONTEXT}

According to the action proposal, elaborated in a course atPUC SP (PontifíciaUniversidadeCatólica São Paulo), in April 2009, a serial meetings at Fatec-Jahu were carried out, adding up to 20 (twenty) hours, involving voluntary professors and one course coordinator, besides the participants and authors of this article. The lectures were divided into two parts: the first one, theoretical, and the second one, in practice. The theory was headed by group discussions on several topics, like as, teaching practice and theory; the ICT role and concepts; and the necessary structure for at distance teaching. As practices, the use of tools like MovieMakerandPowerPoint; theLearning Center atFatec-Jahu; and, finally, Concept Map notions, using theIHMC ${ }^{4}$ CMap Toolssoftware. The practices allowed the utilization and insertion of contents, forums, and other available resources at FatecJahu VLE.

The target of such action was to talk about how the resources placed at the site could help for the teaching process and the possibility of insertion of the school professors in a virtual environment, besides offering and encouraging the educators to use the available new technologies at Fatec-Jahusince 2006 but still have little utilization by the educators of the institution.Before the lectures, a course plan was created and two polls were performed:one sampling with one hundred and fifty-four (154)students of all semesters and courses at FatecJahu;another one with twenty-four (24) professors, in order to get a diagnosis of the current circumstances at the scene. The sampling was random and the quiz was directed to be familiar with the learning center user profile, his/her knowledge and/or use of new technologies in educational practices.

\section{FINDINGS- FATEC JAHUSTUDENTS' PROFILE}

The sampling subject researched had THE following profile: $45 \%$ were 17 to 20 years old, $46 \%$ were 21 to 30 years old, and $9 \%$ were older; $59 \%$ were male students which showed that most students were young men. $91 \%$ of the students claimed that their professors used technological resources and the most cited ones were multimedia projectors and computers. Moreover, $71 \%$ said that they had no problems in solving doubts in classes; the students who had problems, $76 \%$ asked their classmates to help them to solve the doubts. $64 \%$ of the interviewee declared they would like means would be offered,such as prefects and full time attendance,to help them with their doubts. Among the most used resources used by their professors in class, the most cited ones were: $88 \%$, multimedia projectors; $82 \%$, blackboard and chalk; 68\%,supplementary texts; $58 \%$, photocopies; $42 \%$, internet; and only $23 \%$, the learning center site. $98 \%$ of the students said they had computers and $97 \%$, internet access (54\%, DSL, 23\% ISDN; and 19\%, via radio). Internet was used mainly for research (88\%), emailing (85\%), and playing games (30\%). The most cited softwares were text editors $(81 \%)$, presentation $(74 \%)$, spreadsheet $(71 \%) .52 \%$ of the interviewee affirmed that they did not use the learning center site. The ones who used it, $96 \%$ claimed that the site was used by them to access the content and $43 \%$ to do the tasks they are asked to. $81 \%$ asserted they had never attended to at distance courses. $51 \%$ claimed that their professors did not use the learning center site either; however, $51 \%$ of the interviewees affirmed that they would like their professors to use such learning virtual environment (LVE) and the most cited reasons were they would have access to content and exercises, besides forums and debates for necessary explanations.

\section{FINDINGS -FATECJAHUPROFESSORS'PROFILE}

The sampling with educators gathered the opinion of 24educators, who were investigated and chosen at random, and were not taking part of the qualification. It represented about thirty percent (30\%) of all the educators hired at FatecJahu, and most of them taught to several semesters and courses of the institution. The results were: the age results of the interviewees were $-15 \%$ are 20 to 30 years old; $45 \%$ are 31 to 49 years old, and $40 \%$ are over 40. About their degree, 10 had Bachelor's degree, 5 hadAssociate's degree in teaching and 8 had Associate's degree in technology, assuming that some professors had more than one higher degree. $70 \%$ marked that had been working at FatecJahu over 2 years; $15 \%$ for 2 years; and $15 \%$ for 1 year. $80 \%$ indicated that they had a permanent labor contract and $20 \%$ had a fixed term employment. $80 \%$ were part -time workers and $20 \%$ were full-time ones. $90 \%$ claimed to use technological resources at present classes, and the multimedia

${ }^{4}$ Institute for Human and Machine Cognition

DOI: 10.9790/0837-2109012630 $\quad$ www.iosrjournals.org $\quad 28 \mid$ Page


projector was the most used device (50\%). $60 \%$ of the interviewees did not notice if their students had any difficulties to clarify their doubts in class, but $35 \%$ affirm they did, so $42 \%$ said they asked such students to look for them after classes. The most indicated resources used to support classes were: $85 \%$ - blackboard and chalk; $80 \%$ - multimedia projector; $70 \%$ - internet; and $65 \%$ - supplementary texts. $95 \%$ of the professors indicated they used internet to perform researches, e-mailing, and $80 \%$ to prepare class note, besides $30 \%$ of usage in at distance courses. The most used softwares were text editors (95\%), presentation (90\%), spreadsheet $(85 \%)$. $35 \%$ of the professors had already taken part in at distance courses and $80 \%$ claimed they did not use the learning center site at FatecJahu. The ones who used it claimed to offer some content and tasks. $65 \%$ of the professor asserted that the site was not used because they did not had time or did not know to use it. $60 \%$ of the interviewees declared they had never accessed the learning center site, but $75 \%$ would like to include such resource.

\section{THE QUALIFICATION PROCESS - CONSIDERATIONS AND RESULTS}

The first lectures approached the difference between teaching and having classes, their consequences on learning, as well as the discernment between information and knowledge. The partners concluded that teaching practice, in general, is related to having classes, i.e., information is taught using the board or audiovisual equipment. There is not a process to transform them into knowledge. Professors noticed a model to transfer information, as it is shown in the diagram below:

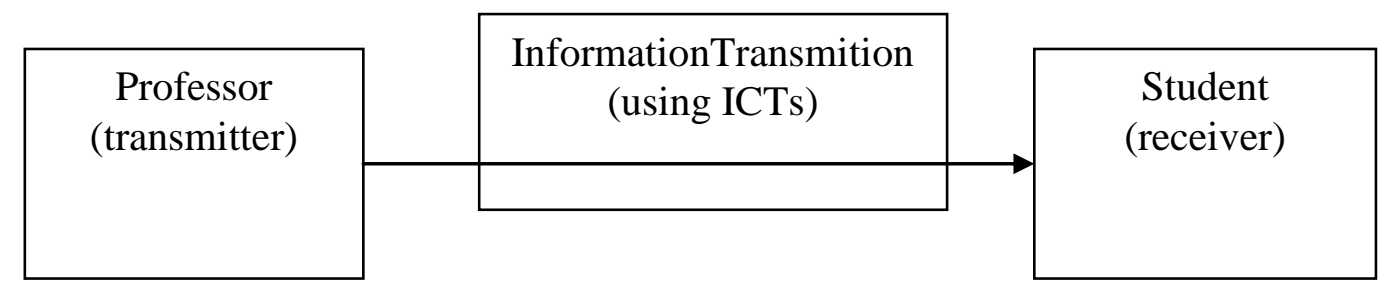

Picture3.Information Delivery Model

Although FatecJahu Teaching Plans consider the educational resources and teaching methods, the professor barely prepares his/her classes eventually, and, in that case, the Teaching Plan has the purpose of a formal duty. For most professors the ICTs are limited to the facilities, exactly materials, then the educational aspects of the resources are brushed aside.

During the meetings a discussion about advantages and disadvantages of a merely explanation class using the board as a resource, and datashow(multimedia projector), to show slides, creating movies and using VLEs was done. The group concluded that each teaching method has problems and it the educator's role to plan a better strategy in order to consider the subject to be taught or instructed, as well as the features of each student and/or student class. The early outlook that for each kind of classe there is an adequate method, subject or group was changed after the lectures and it was verified and assumed that the educator should use several resources, according to the teaching situation.

\section{FINAL CONSIDERATIONSABOUTTHEPROCESS}

The poll result evaluation let the conclusion that the professor is interested to add new technologies to teaching practice; however, the VLE is not being used as he/she has little contactwith such teaching mode. It is noticed that the tool is seldom used because it is not well-known and there is a large amount of professors who do not use it due to habit to his/her usual teaching methods besides presuming that its use may compromise his/her educational practices somehow and also because he/she will be frequently being tested about how the contents are shown. On the other hand, it is perceived that students are curious and interested on trying at distance mode in teaching / learning process, but he/she is not ready to use and explore all the resources offered by such mode, despite verifying that mostof them have a computer and can make good use of VLEs.In the lectures it was observed that the professor has not had knowledge that, somehow, he is adverse and oldfashioned to new teaching practices, causing overuse of explanation classes. Maybe that is because of his/her own learning process modeling as a student. Most professors who attended to the lectures assumed that there is a false notion between teaching and having classes. Their most frequent complaint is that the students are not grown or prepared to enter a graduation course, what is partly true, but it reinforces the typical and classical scene of content classes where the educator is the center of information and transmits it by means of displaying data in classes.According to the educators, it has been concluded that the use of multimedia resources 
(datashowprojectors, OHPs, internet, etc.) comes classes alive and easier to be assimilated by the students; nevertheless, according to the students classes may be boring, if such equipments are misused. The educational quests about teaching process are practically unknown by the educators, hence, they are brushed aside. As a consequence to that, it is noted that professors consider contents more important than the educational practice, admitting unconsciously that the learning process is only a student's matter. About the professor's attitude discussion, the authors concluded that there is a large difference between having resources to facilitate class practice and knowing how to use the resources to facilitate learning.

Also, it is clear that VLE should be used carefully as it is not just an informational repository or even become a questionnaire reference, paying attention not to trivialize its use in order to reduce costs. O blended learning ${ }^{5}$ is an interesting way, and should be taken into consideration to be studied, in order to be potentially put into practice, The VLEs model implementation should take account of a cultural change that allows educators to be more conscious and worried about teaching practices, qualifying him/her to be a expert and mediator of the process and who takes into consideration the student to learn how to be organized and applied.

\section{REFERENCES}

[1] ANTUNES, C. (2002). Novas Maneiras e Ensinar, novas maneiras de aprender. Porto Alegre: Artmed.

[2] BARROS, D. M. (2003). Educação a Distância e o Universo do Trabalho. Bauru, São Paulo: EDUSC.

[3] DOWBOR, L. (2001). Tecnologias do Conhecimento: Os Desafios da Educação. Petrópolis: Vozes.

[4] LiTTO, F., \& FORMiGA, M. (2009). Educação a Distância: o Estado da Arte. São Paulo: Pearson Education do Brasil.

[5] Lopes, A. M., \& $\quad$ Gomes, $\quad$ M. $\quad$ J. https://repositorium.sdum.uminho.pt/bitstream/1822/7098/1/Challenges07-AML-MJG.pdf. Acesso em 29 de Abril de 2009, disponível em Universidade do Minho:página principal: https://repositorium.sdum.uminho.pt/bitstream/1822/7098/1/Challenges07-AML-MJG.pdf

[6] MAIA, C., \& MATTAR, J. (2007). ABC do EaD.São Paulo: Pearson Prentice Hall.

[7] MASETTO, M. (1998). Docência na Universidade. Campinas: Papirus .

[8] Ministério da Ciência e Tecnologia. (4 de Agosto de 2000). http://www.fsp.usp.br/acessibilidade/LivroVerdeSOCINFO-240701.pdf. Acesso em 29 de Abril de 2009, disponível em FSP/USP - Faculdade de Saúde Pública: http://www.fsp.usp.br/acessibilidade/LivroVerdeSOCINFO-240701.pdf

[9] Novais, V. L. (2004). www.eadconsultoria.com.br/matapoio/biblioteca/textos_pdf/texto07.pdf. Acesso em 19 de Abril de 2009, disponível em ead consultoria: http://www.eadconsultoria.com.br/matapoio/biblioteca/textos_pdf/texto07.pdf

[10] PERRENOUD, P. (2000). 10 Novas Competências para Ensinar. Porto Alegre: ARTMED Editora.

[11] PORTO, C., \& RÉGNIER, K. (Dezembro de 2003). http://www.unemat.br/prpdi/pdi/docs/ensino_superior_mundo_brasil_tendencias_cenarios_2003_2025. Acesso em 17 de Dezembro de 2008, disponível em Portal UNEMAT - Universidade do Estado de Mato Grosso:

http://www.unemat.br/prpdi/pdi/docs/ensino_superior_mundo_brasil_tendencias_cenarios_2003_2025.pd $\mathrm{f}$

[12] Tusset, A. M. (2006). As tecnologias e sua influência na educação à distância. Revista Linh@ Virtual Concórdia, Santa Catarina, Brasil. 